\title{
Evaluating ecological risks and tracking potential factors influencing heavy metals in sediments in an urban river
}

\author{
Dongping Liu' ${ }^{1}$ Jian Wang ${ }^{1,2}$, Huibin $\mathrm{Yu}^{1{ }^{*}}$, Hongjie Gao ${ }^{1 *}$ and Weining $\mathrm{Xu}^{1}$
}

\begin{abstract}
Background: Heavy metal pollution of aquatic systems is a global issue that has received considerable attention. Canonical correlation analysis (CCA), principal component analysis (PCA), and potential ecological risk index (PERI) have been applied to heavy metal data to trace potential factors, identify regional differences, and evaluate ecological risks. Sediment cores of $200 \mathrm{~cm}$ in depth were taken using a drilling platform at 10 sampling sites along the Xihe River, an urban river located in western Shenyang City, China. Then they were divided into 10 layers $(20 \mathrm{~cm}$ each layer). The concentrations of the $\mathrm{As}, \mathrm{Cd}, \mathrm{Cr}, \mathrm{Cu}, \mathrm{Hg}, \mathrm{Ni}, \mathrm{Pb}$ and $\mathrm{Zn}$ were measured for each layer. Eight heavy metals, namely Pb, $\mathrm{Zn}, \mathrm{As}, \mathrm{Cd}, \mathrm{Cr}, \mathrm{Cu}, \mathrm{Ni}$, and $\mathrm{Hg}$, were measured for each layer in this study.

Results: The average concentrations of the $\mathrm{As}, \mathrm{Cd}, \mathrm{Cu}, \mathrm{Hg}$, and $\mathrm{Zn}$ were significantly higher than their background values in soils in the region, and mainly gathered at 0-120 cm in depth in the upstream, 0-60 cm in the midstream, and $0-20 \mathrm{~cm}$ downstream. This indicated that these heavy metals were derived from the upstream areas where a large quantity of effluents from the wastewater treatment plants enter the river. $\mathrm{Ni}, \mathrm{Pb}$, and $\mathrm{Cr}$ were close or slightly higher than their background values. The decreasing order of the average concentration of $\mathrm{Cd}$ was upstream $>$ midstream > downstream, so were $\mathrm{Cr}, \mathrm{Cu}, \mathrm{Ni}$ and $\mathrm{Zn}$. The highest concentration of As was midstream, followed by upstream and then downstream, which was different to $\mathrm{Cd}$. The potential factors of heavy metal pollution were $\mathrm{Cd}$, $\mathrm{Cu}, \mathrm{Hg}, \mathrm{Zn}$, and $\mathrm{As}$, especially $\mathrm{Cd}$ and $\mathrm{Hg}$ with the high ecological risks. The ecological risk levels of all heavy metals were much higher in the upstream than the midstream and downstream.

Conclusions: Industrial discharge was the dominant source for eight heavy metals in the surveyed area, and rural domestic sewage has a stronger influence on the Hg pollution than industrial pollutants. These findings indicate that effective management strategies for sewage discharge should be developed to protect the environmental quality of urban rivers.
\end{abstract}

Keywords: Heavy metals, Canonical correlation analysis, Principal component analysis, Potential ecological risk index

\section{Background}

With recent advances in industrialization and socioeconomic development, heavy metal pollution of aquatic systems has become a global issue and has received

\footnotetext{
*Correspondence: yhbybx@163.com; ghjlxh@sina.com

${ }^{1}$ State Key Laboratory of Environmental Criteria and Risk Assessment, Chinese Research Academy of Environmental Science, Beijing 100012, People's Republic of China

Full list of author information is available at the end of the article
}

considerable attention due to high biotoxicity, wide sources, non-biodegradability, and bio-enrichment in food webs [1-3]. River sediments have been identified as important carriers and sinks for the heavy metals discharged into the aquatic systems $[4,5]$. Heavy metals in river sediments mainly stem from rock weathering, soil erosion, runoff from agriculture, sewage treatment, and atmospheric precipitation [6, 7]. The heavy metals loaded into the river environment can be transferred to and concentrated in sediments together with organic matter, Fe/
Springer Open

(C) The Author(s) 2021. This article is licensed under a Creative Commons Attribution 4.0 International License, which permits use, sharing, adaptation, distribution and reproduction in any medium or format, as long as you give appropriate credit to the original author(s) and the source, provide a link to the Creative Commons licence, and indicate if changes were made. The images or other third party material in this article are included in the article's Creative Commons licence, unless indicated otherwise in a credit line to the material. If material is not included in the article's Creative Commons licence and your intended use is not permitted by statutory regulation or exceeds the permitted use, you will need to obtain permission directly from the copyright holder. To view a copy of this licence, visit http://creativeco mmons.org/licenses/by/4.0/. 
Mn oxides, and sulfides by adsorption and accumulation on suspended fine-grained particles, however they cannot be permanently fixed in sediments [8-10]. Under ecological disturbances such as a decline in redox potential or $\mathrm{pH}$ and the degradation of organic matter, the heavy metals in sediments can be released back into the overlying water by various processes of remobilization, which may lead to secondary pollution [11-13].

The degree of each heavy metal pollution in the sediment is different, so that it is essential to clarify the internal correlation of heavy metals with sediments, and trace the potential factors of heavy metal pollution. Statistical method is used widely in studying the relationship between different heavy metal concentrations and samples. Canonical correlation analysis (CCA) and principal component analysis (PCA) are the most common multivariate statistical methods used in environmental studies, which provide techniques for classifying interrelationship of heavy metals and samples $[14,15]$. CCA could elaborate on the relationship between observed variables, and track the latent factors [16]. PCA is widely used to reduce data, extract a small number of latent factors, and discriminate the similarity and dissimilarity for analyzing relationships among the observed variables [17].

A variety of evaluation methods for heavy metals have been developed by international organizations and conventions, which have been applied to evaluate heavy metal pollution and the potential ecological risks in the sediments. These methods are associated with the enrichment factor, pollution degree, pollution load index, pollution factor, and geo-accumulation index, which may be mainly used to evaluate the ecological risks according to the ratio of a single heavy metal concentration to the background value [18-23]. However, these methods neither provide information on the toxicity of heavy metals nor indicate the comprehensive toxic effects in the overall heavy metal assemblage. The potential ecological risk index (PERI), developed by the famous Swedish scholar Håkanson, is a well-known method for the potential risk of heavy metal pollution in soils and sediments, which could fill this gap and consider both total contents of heavy metals and the toxic response factors for each heavy metal [24-26]. The PERI had been applied on the diagnostic for water pollution control, the evaluation of potential ecological risk of heavy metals in the Yellow River sediments and the assessment of heavy metal pollution in marine sediments, and so on [24, 25].

Therefore, CCA, PCA and PERI were used to explore the spatial variations and trace potential factors, to identify regional differences, and to assess the potential ecological risks of heavy metals, namely $\mathrm{As}, \mathrm{Cd}, \mathrm{Cr}, \mathrm{Cu}$, $\mathrm{Hg}, \mathrm{Ni}, \mathrm{Pb}$, and $\mathrm{Zn}$, in the sediments of the Xihe River, an urban river located in Shenyang City, China. The proposed studies on the distribution characteristics and potential ecological risks of the heavy metals in sediments of Xihe River are expected to provide theoretical support and scientific basis for the effective sewage discharge management of Xihe River, and then effectively improve the water quality of the urban river.

\section{Materials and methods \\ Description of study area}

The Xihe River, a tributary of the Hunhe River, is located in the western part of Shenyang City, China, and extends $78.2 \mathrm{~km}$ through the Tiexi Industrial District (Fig. 1). It experiences a temperate continental monsoon climate. The mean width of the Xihe River is $10.5 \mathrm{~m}$, with a mean annual rainfall of $680.4 \mathrm{~mm}$ [27]. The industry in Tiexi District is dominated by equipment manufacturing, automobiles and parts, industrial tourism and biopharmaceutical, and the industrial park has economic-technical development zone, chemical industry park, metallurgical industry park and export processing zone. The average runoff volume of Xihe River is about $924,500 \mathrm{~m}^{3}$ day $^{-1}$ dominated by industrial wastewater $(67.73 \%)$ and domestic (19.79\%), and effluents from wastewater treatment plants are released directly into the river $[28,29]$. Therefore, large quantities of pollutants are discharged into the river, which can lead to water quality deterioration and ecosystem degradation. In particular, the continuous accumulation of heavy metals in the sediments may induce potential ecological risks.

\section{Sampling and analysis}

Field observations and sampling campaigns to collect sediments in the Xihe River were conducted during July 15-25, 2019 (Fig. 1). Three regions were divided along a human impact gradient, the centralized wastewaterdischarge region (upstream), the dispersed wastewaterdischarge region (midstream), and farmland region (downstream). Ten sampling sites were selected cross the urban river. Sampling sites \#1-\#3 were located upstream, where a large amount of effluents from the wastewater treatment plants (WWTP) was loaded into the river. Sampling sites \#4-\#7 were situated in midstream, where a small amount of dispersed wastewater (domestic wastewater and livestock breeding) wastewater were discharged into the river. Sampling sites \#8-\#10 were located downstream, where the partial return water from farmlands enters the river. Sediment cores $200 \mathrm{~cm}$ in length were collected at each site and divided into 10 horizons $(0-20 \mathrm{~cm}, 20-40 \mathrm{~cm}$, $40-60 \mathrm{~cm}, 60-80 \mathrm{~cm}, 80-100 \mathrm{~cm}, 100-120 \mathrm{~cm}, 120-$ $140 \mathrm{~cm}, 140-160 \mathrm{~cm}, 160-180 \mathrm{~cm}$, and $180-200 \mathrm{~cm}$ ). Each sediment horizon was thoroughly mixed and homogenized after carefully removing gravel, shells, 


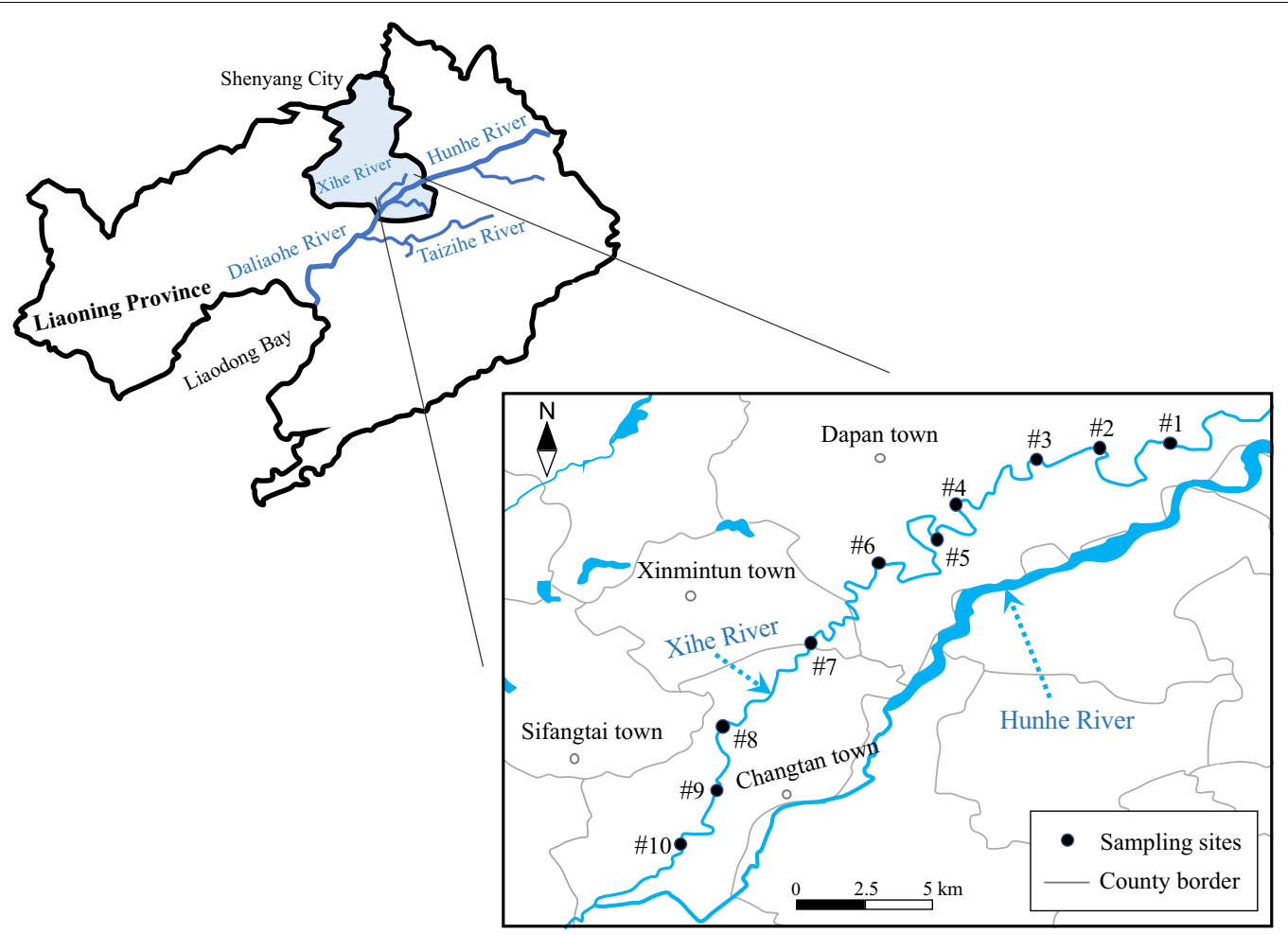

Fig. 1 Watersheds of the Xihe River and location of the sampling sites

and animal and plant residues. The samples were stored at $4{ }^{\circ} \mathrm{C}$ until they returned to the laboratory.

In a given sediment sample, $5 \mathrm{~g}$ of freeze-dried and sieved $(\varnothing=100)$ sediment was digested in $5 \mathrm{~mL}$ solution of $\mathrm{HNO}_{3}$ and $\mathrm{HClO}_{4}$ at $140{ }^{\circ} \mathrm{C}$ for $3 \mathrm{~h}$ [30]. After the samples were cooled, the content of each tube was diluted to $25 \mathrm{~mL}$ with double distilled water. The digested samples were then filtered. The concentrations of the As, $\mathrm{Cd}, \mathrm{Cr}, \mathrm{Cu}, \mathrm{Hg}, \mathrm{Ni}, \mathrm{Pb}$, and $\mathrm{Zn}$ were determined for each sample using ICP-MS (ELAN DRC II model, Perkin-Elmer Sciex, Norwalk, CT, USA), with sediment standard substance (Chinese geological reference materials GBW07309) used for quality control during the analysis process. Three parallel samples were set up and the relative standard deviations of the heavy metals for the multiple measurements were less than $5 \%$.

\section{Pollution assessment method}

Recently, different indicators has been utilized to estimate the heavy metal pollution and risk in sediments. PERI was used in this study to represent the potential ecological risk index of heavy metals in the sediments of the Xihe River. It was calculated according to the following formula:

$$
\begin{aligned}
& C_{f}^{i}=\frac{C_{s}^{i}}{C_{n}^{i}}, \\
& E_{r}^{i}=T_{r}^{i} \cdot C_{f}^{i}, \\
& \text { PERI }=\sum_{i=1}^{n} E_{r}^{i},
\end{aligned}
$$

where $E_{r}^{i}$ is the potential ecological risk associated with the heavy metal $i$ in the sediments, which is the product of the toxic response factor $T_{r}^{i}$ and the pollution factor $C_{f}^{i}$. $T_{r}^{i}$ is the toxic response factor of heavy metals $i$ and has values of $10,30,2,5,40,5,5$ and 1 for $\mathrm{As}, \mathrm{Cd}, \mathrm{Cr}, \mathrm{Cu}, \mathrm{Hg}$, $\mathrm{Ni}, \mathrm{Pb}$, and $\mathrm{Zn}$, respectively [31]. $C_{f}^{i}$ is the pollution factor of heavy metals $i$, which is the ratio between the determined concentration in the sediment $C_{s}^{i}$ and the background value $C_{n}^{i}$ (Table 1 ). The background value for the soil in Liaoning Province were used as $C_{n}^{i}$ [32]. According to Zhang et al. [33], the individual ecological risk of heavy metals and integrated potential ecological risk can be classified into the categories shown in Table 2.

\section{Statistical analysis}

Variations in heavy metal values were presented using sediment depth and sampling site matrices. CCA and 
Table 1 Background values ( $\mathrm{mg} \mathrm{kg}^{-1}$ ) of heavy metals in Liaoning Province of China

\begin{tabular}{lllllllll}
\hline Heavy metals & As & $\mathrm{Cd}$ & $\mathrm{Cr}$ & $\mathrm{Cu}$ & $\mathrm{Hg}$ & $\mathrm{Ni}$ & $\mathrm{Pb}$ & $\mathrm{Zn}$ \\
\hline Background & 8.80 & 0.16 & 57.66 & 24.57 & 0.05 & 25.60 & 22.15 & 59.84 \\
\hline
\end{tabular}

Table 2 Grade standards for potential ecological risks

\begin{tabular}{|c|c|c|c|c|c|}
\hline Risk level & Low risk & $\begin{array}{l}\text { Moderate } \\
\text { risk }\end{array}$ & High risk & $\begin{array}{l}\text { Very high } \\
\text { risk }\end{array}$ & $\begin{array}{l}\text { Disastrous } \\
\text { risk }\end{array}$ \\
\hline Grade & 1 & $\|$ & III & IV & V \\
\hline$E_{r}^{i}$ & $<30$ & $30-60$ & $60-120$ & $120-240$ & $>240$ \\
\hline PERI & $<100$ & $100-200$ & $200-400$ & $>400$ & \\
\hline
\end{tabular}

PCA were carried on the data matrices of the heavy metals to trace the potential factors and reveal the patterns of the sediment samples $[34,35]$. The score plots for heavy metals can characterize the potential factors of each principal components (PC), and the loading plots for the 10 sediment layers can be used to investigate the sedimentary characteristics of the heavy metals. All statistical analyses were performed using Canoco 5, SPSS 22, and Origin 8.0 software for windows.

\section{Results and discussion}

\section{Concentrations of heavy metals in sediments}

The average concentrations of eight heavy metals in sediment samples from the Xihe River are presented in Table 3. Based on the average concentrations, the pattern in sediment was: $\mathrm{Zn}(205.68 \pm 243.96)>\mathrm{Cu}$ $(45.25 \pm 83.14)>\mathrm{Cr}(35.55 \pm 58.96)>\mathrm{Ni}(35.06 \pm 44.08)>\mathrm{Pb}$ $(21.88 \pm 13.68)>$ As $(11.19 \pm 21.04)>\mathrm{Cd}(2.88 \pm 5.34)>\mathrm{Hg}$ $(1.01 \pm 2.17)$. The minimum concentration was observed for the known toxic elements (such as $\mathrm{Cd}, \mathrm{Hg}$, and $\mathrm{Pb}$ ) while the maximum concentration was observed for $\mathrm{Cu}$ and $\mathrm{Zn}$. Copper and zinc pollution of sediments possibly arisen from effluents from municipal and mining, furthermore the highest concentrations of $\mathrm{Cu}$ and $\mathrm{Zn}$ could also be related to the geological sources in addition to anthropogenic inputs [36].

Table 3 also summarizes the average concentration of the eight heavy metals from other urban rivers to understand the extent of heavy metal pollution of the study

Table 3 Average heavy metals concentrations $\left(\mathrm{mg} \mathrm{kg}^{-1}\right)$ in sediment from Xihe River and other urban rivers of the world

\begin{tabular}{|c|c|c|c|c|c|c|c|c|c|}
\hline & As & $\mathrm{Cd}$ & $\mathrm{Cr}$ & $\mathrm{Cu}$ & $\mathrm{Hg}$ & $\mathrm{Ni}$ & $\mathrm{Pb}$ & $\mathrm{Zn}$ & Reference \\
\hline Xihe River & $11.19 \pm 21.04$ & $2.88 \pm 5.34$ & $35.55 \pm 58.96$ & $45.25 \pm 83.14$ & $1.01 \pm 2.17$ & $35.06 \pm 44.08$ & $21.88 \pm 13.68$ & $205.68 \pm 243.96$ & This study \\
\hline $\begin{array}{l}\text { Dongbao } \\
\text { River } \\
\text { (China) }\end{array}$ & - & $1.27 \pm 0.16$ & $713.00 \pm 169.00$ & $2602.00 \pm 336.00$ & - & $412.00 \pm 93.00$ & $69.90 \pm 6.17$ & $646.00 \pm 30.00$ & [38] \\
\hline $\begin{array}{l}\text { Xixiang River } \\
\text { (China) }\end{array}$ & - & - & $89.58 \pm 43.99$ & $168.82 \pm 72.29$ & $0.48 \pm 0.25$ & $69.46 \pm 30.58$ & $62.96 \pm 24.89$ & $310.33 \pm 111.26$ & {$[39]$} \\
\hline $\begin{array}{l}\text { Gushu } \\
\text { Chung } \\
\text { (China) }\end{array}$ & - & - & $112 \pm 55.25$ & $162.33 \pm 108.65$ & $0.11 \pm 0.15$ & $68.00 \pm 45.40$ & $75.60 \pm 23.78$ & $487.33 \pm 312.57$ & [39] \\
\hline $\begin{array}{l}\text { Shiqiao River } \\
\text { (China) }\end{array}$ & - & $2.79 \pm 1.31$ & $133.00 \pm 26.00$ & $100.00 \pm 47.00$ & - & $66.00 \pm 25.00$ & $96.00 \pm 30.00$ & $327.00 \pm 76.00$ & [40] \\
\hline $\begin{array}{l}\text { Korotoa River } \\
\text { (Bangla- } \\
\text { desh) }\end{array}$ & $22.00 \pm 16.00$ & $1.00 \pm 0.53$ & $99.00 \pm 38.00$ & $71.00 \pm 27.00$ & - & $86.00 \pm 34.00$ & $54.00 \pm 15.00$ & - & [41] \\
\hline $\begin{array}{l}\text { Nakivubo } \\
\text { Chan- } \\
\text { nelized } \\
\text { stream } \\
\text { (Uganda) }\end{array}$ & - & $0.05 \pm 0.002$ & - & $6.75 \pm 0.13$ & - & - & $10.00 \pm 0.98$ & $48.25 \pm 1.04$ & [42] \\
\hline $\begin{array}{l}\text { Karnaphuli } \\
\text { River } \\
\text { (India) }\end{array}$ & - & - & $96.67 \pm 11.14$ & $31.39 \pm 8.57$ & - & $42.94 \pm 6.04$ & $25.33 \pm 1.27$ & $73.93 \pm 13.74$ & [43] \\
\hline $\begin{array}{l}\text { Akai River } \\
\text { (Ethiopia) }\end{array}$ & - & $2.60 \pm 0.20$ & $18.30 \pm 1.02$ & $2.10 \pm 0.01$ & - & $14.60 \pm 0.98$ & $111.50 \pm 1.09$ & $10.30 \pm 0.02$ & [36] \\
\hline $\begin{array}{l}\text { Strzyza } \\
\text { Stream } \\
\text { (Poland) }\end{array}$ & - & $0.19 \pm 0.18$ & $18.22 \pm 19.36$ & $36.63 \pm 56.49$ & - & $8.68 \pm 7.87$ & $45.89 \pm 63.00$ & $149.51 \pm 201.38$ & {$[44]$} \\
\hline $\begin{array}{l}\text { Calore River } \\
\text { (Italy) }\end{array}$ & $7.30 \pm 3.60$ & $0.23 \pm 0.20$ & $19.70 \pm 9.00$ & $34.30 \pm 20.30$ & $0.08 \pm 0.19$ & $24.60 \pm 11.90$ & $24.00 \pm 21.20$ & $65.90 \pm 49.44$ & [45] \\
\hline
\end{tabular}


area. The $\mathrm{Cd}$ and $\mathrm{Hg}$ contamination in sediments of this study was relatively higher than the values from all the other studies. The average concentration of $\mathrm{Cd}$ was 17.98 times higher than its background value, and the $\mathrm{Hg}$ average concentration was 20.16 times higher than its background value, indicating that $\mathrm{Cd}$ and $\mathrm{Hg}$ pollution was remarkable in sediment of Xihe River. The average concentrations of $\mathrm{As}, \mathrm{Cr}, \mathrm{Cu}, \mathrm{Ni}, \mathrm{Pb}$, and $\mathrm{Zn}$ were within the ranges observed in the other studies, and $\mathrm{Cr}$ and $\mathrm{Pb}$ were lower than their background values. Additionally, the average concentrations of $\mathrm{As}, \mathrm{Cu}, \mathrm{Ni}$, and $\mathrm{Zn}$ were 1.273.44 times higher than their background values, which indicated the Xihe River sediments were seriously polluted. Overall, this comparison indicated that there was the high accumulation of heavy metals in the sediments of Xihe River and that it requires special care and management interventions such as proper waste collection, treatment, and disposal [37].

\section{Spatial distributions of heavy metals in sediments}

Spatial distributions were obtained through the matrices of the heavy metals in the Xihe River (Fig. 2). The average concentrations ( $\mathrm{mg} \mathrm{kg}^{-1}$ ) of the heavy metals across all the sediments in decreasing order was as follows: $\mathrm{Zn}>\mathrm{Cu}>\mathrm{Cr}>\mathrm{Ni}>\mathrm{Pb}>\mathrm{As}>\mathrm{Cd}>\mathrm{Hg}$. The average concentration of the As was the highest at the downstream sites, followed by the midstream and upstream (Fig. 2a). As concentrations were highest at the surface layers of all sites except for site \#1 and site \#2, which were much higher than the background values at sites \#6, \#9, and \#10. Cd concentrations in all the layers of each site were far higher than their background values (Fig. 2b). The average concentration of $\mathrm{Cd}$ was the highest in the upstream, followed by the midstream and downstream. The concentrations in the $80-100 \mathrm{~cm}$ layer of site \#1 and the $0-20 \mathrm{~cm}$ layer of site \#6 were much higher than those in the other sediment layers. The average concentration trend of the $\mathrm{Cr}$ in the upstream, midstream, and downstream regions was similar to that of $\mathrm{Cd}$. However, the concentrations in the whole layers at all sites were lower than their background value. The maximum concentration was observed in the $140-160 \mathrm{~cm}$ horizon of site \#2 (Fig. 2c). For the midstream and downstream sites, the concentrations were highest in the $0-20 \mathrm{~cm}$ layers. At all sites, the $\mathrm{Cu}$ concentrations in all 10 layers were much higher than their background values (Fig. 2d). The trend of the mean $\mathrm{Cu}$ values in the upstream, midstream, and downstream regions was similar to that of $\mathrm{Cd}$ and $\mathrm{Cr}$; being higher at the upstream sites. The maximum concentration of $\mathrm{Cu}$ occurred in the $60-80 \mathrm{~cm}$ layer of site $\# 1$.
The background values of $\mathrm{Hg}$ were higher than the concentrations found at any layer of any site (Fig. 2e). The decreasing order of the average $\mathrm{Hg}$ concentration was midstream $>$ upstream $>$ downstream. The maximum concentration occurred in the $0-20 \mathrm{~cm}$ layer of site \#6. The maximum concentration of the $\mathrm{Ni}$ was found in the $0-20 \mathrm{~cm}$ layer at all sites except for site \#1, where the maximum was in the $80-100 \mathrm{~cm}$ layer (Fig. 2f). The trend of $\mathrm{Ni}$ in the upstream, midstream, and downstream regions was the same as that of $\mathrm{Cd}, \mathrm{Cr}$, and $\mathrm{Cu}$. Furthermore, the $\mathrm{Ni}$ concentrations in the layers $60-100 \mathrm{~cm}$ of site \#1 and $0-20 \mathrm{~cm}$ of site \#2 were higher than the background value, while the concentrations in the remaining layers were close to the background value. Interestingly, the concentrations of $\mathrm{Pb}$ were much lower at depths of the 40-100 cm (Fig. 2g). This indicated that the Pb content in the sediments was very low during a period of time. The $\mathrm{Pb}$ concentrations in all the layers were lower than their background values at all sites, especially at depths of 40-100 cm. Zn concentrations in all the layers were far higher than their background values at all the sites (Fig. 2h). The trend of the $\mathrm{Zn}$ concentrations was similar to that of $\mathrm{Cd}, \mathrm{Cr}, \mathrm{Cu}$, and $\mathrm{Ni}$, being highest at the upstream sites and getting lower as you go downstream. The maximum concentration occurred in the $80-100 \mathrm{~cm}$ layer of the site \#1, while the minimum concentration in the 80-100 cm layer at the site \#10.

The average concentrations of $\mathrm{As}, \mathrm{Cd}, \mathrm{Cu}, \mathrm{Hg}$, and $\mathrm{Zn}$ in all the sediments were significantly higher than their background values in soils in the region. These heavy metals mainly gathered in the top $0-120 \mathrm{~cm}$ of sediments in the upstream areas, in $0-60 \mathrm{~cm}$ midstream, and 0-20 cm downstream, indicating that these metals were derived from the upstream region where a large quantity of effluents from the wastewater treatment plants entered the river [29]. $\mathrm{Ni}, \mathrm{Pb}$, and $\mathrm{Cr}$ were close or slightly higher than their background values. The decreasing order of the average concentrations of As was downstream $>$ midstream > upstream. The trend of $\mathrm{Cd}, \mathrm{Cr}, \mathrm{Cu}, \mathrm{Ni}$, and $\mathrm{Zn}$ was opposite to that of As. The average concentration of $\mathrm{Hg}$ was the highest in the midstream, followed by the upstream and downstream regions, indicating that rural domestic sewage has a stronger influence on $\mathrm{Hg}$ pollution than industrial pollutants [46].

\section{Tracking potential factor and spatial classification}

CCA was used to elaborate on an evident and graphic comprehension of the relationship between water pollution and the heavy metals $[47,48]$. In the CCA ordination biplot, the arrows for $\mathrm{Cu}, \mathrm{Cd}, \mathrm{As}$, and $\mathrm{Hg}$ shoot in the positive direction of the $\mathrm{AX} 1$, while the arrow for $\mathrm{Pb}$ goes in the negative direction (Fig. 3). This indicates that $\mathrm{Cu}, \mathrm{Cd}, \mathrm{As}$, and $\mathrm{Hg}$ have negative correlations with $\mathrm{Pb}$. 

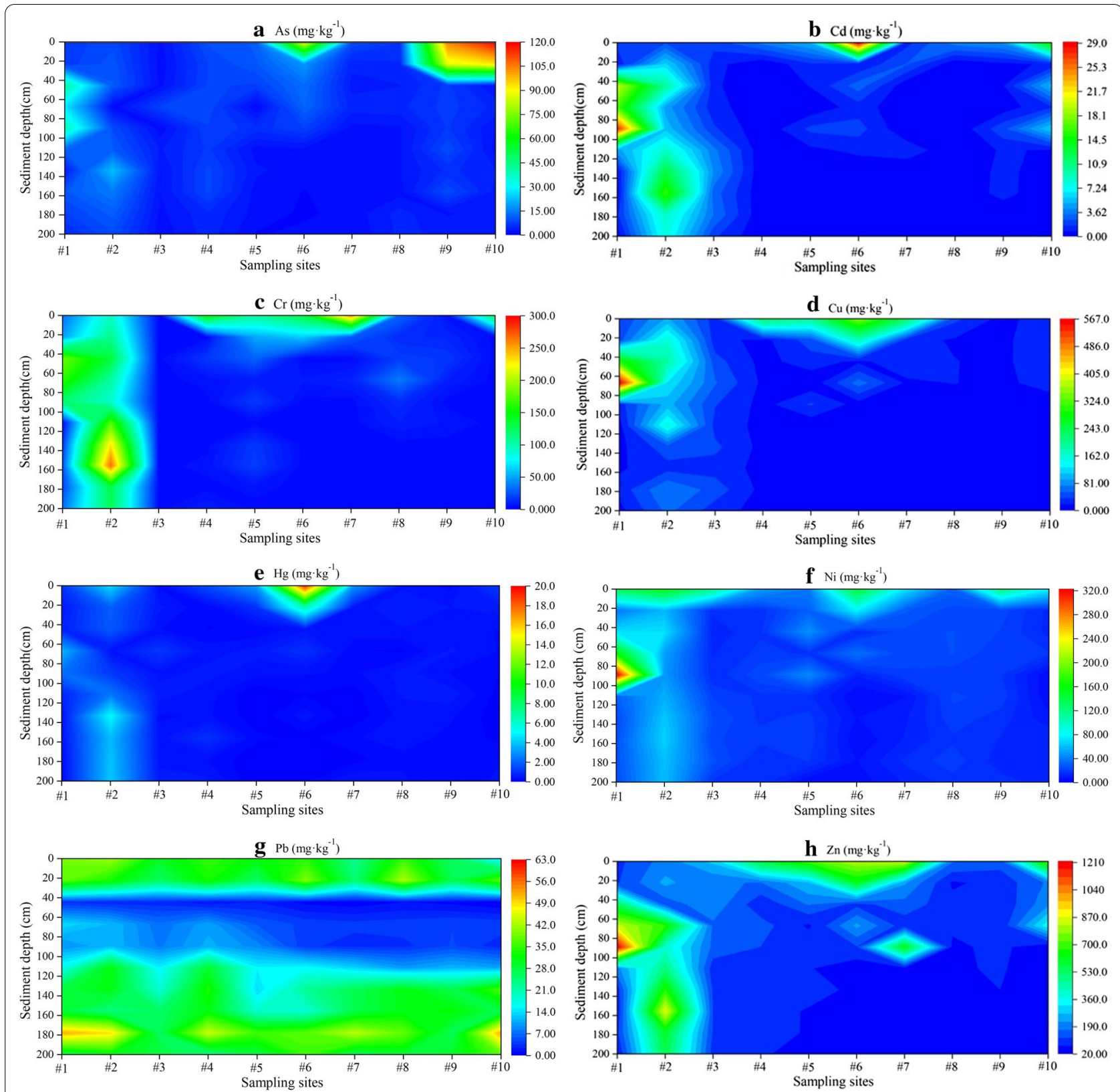

Fig. 2 Spatial distributions of heavy metal parameters in the sediments of Xihe River

The concentration values of $\mathrm{Pb}$ in the sediments were close to their background value or slightly higher. A positive direction for the AX1 might be concerned with the anthropogenic activities, while a negative direction might be related to natural processes [49]. The arrow for $\mathrm{Zn}$ was positive for AX2, while the arrow for $\mathrm{Ni}$ and $\mathrm{Cr}$ was negative. The trends of $\mathrm{Zn}, \mathrm{Ni}$, and $\mathrm{Cr}$ were similar to those of $\mathrm{Cu}, \mathrm{Cd}, \mathrm{Hg}$, As, and $\mathrm{Pb}$. This indicated that the positive direction of the AX2 was associated with anthropogenic activities, while the negative direction was associated with natural conditions [49]. Hence, the potential factors of heavy metal pollution were $\mathrm{Cu}, \mathrm{Cd}$, and $\mathrm{Zn}$, instead of $\mathrm{Pb}, \mathrm{Ni}$, and $\mathrm{Cr}$.

In the ordination biplot, the sediment layers of the sampling sites were roughly divided into two clusters by the straight line $y=x$ (Fig. 3). Cluster A was located under the straight line $y=x$ and contained all sediment layers of sites \#1 and \#2, and the minor partial layers of sites \#4-\#10. Cluster B was located on the straight line $y=x$ and contained most layers of sites \#3-\#10. This 


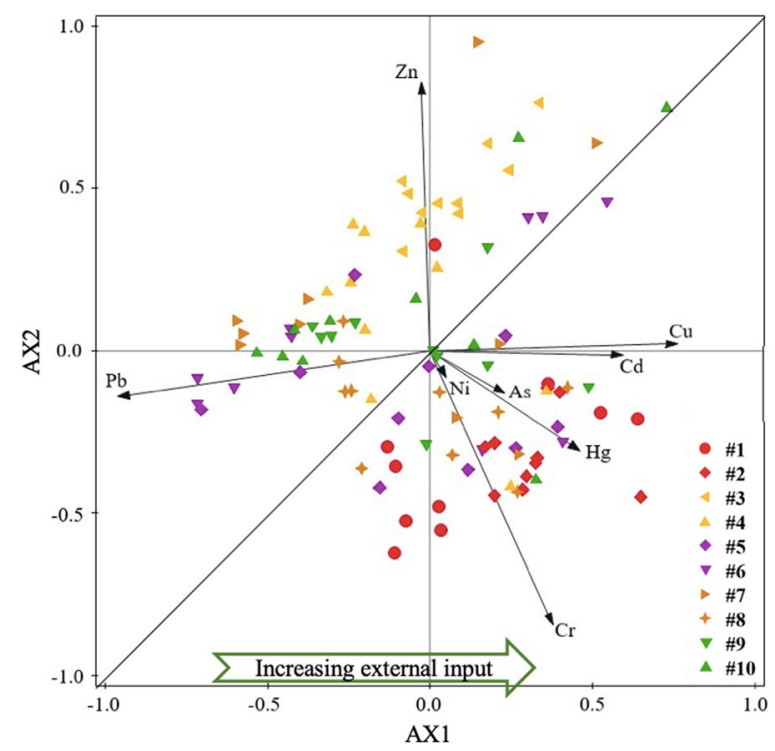

Fig. 3 Ordination biplot based on the CCA of the relationships between the heavy metals and the sediment layers of the sampling sites

indirectly indicated the pollution of heavy metals was more serious upstream than pollution in the midstream and downstream [29]. Moreover, in a given sampling site, the dispersion of the ten layers was relatively larger, which was situated in more than two quadrants. Therefore, the ten layers in each site should be analyzed and discussed independently.

\section{Identifying regional differences}

Kaiser-Meyer-Olkin (KMO) and Bartlett's test of sphericity $(P)$ are usually used to assess the feasibility of PCA [50]. KMO is an index for testing whether the partial correlations among variables are small and $P$ is another index for testing the null hypothesis that the variables in the population correlation matrix are uncorrelated [50, 51]. In general, the KMO value is more than 0.5 and the $P$ value is lower than 0.001 can be viewed as acceptable for PCA. For $P<0.001$ and $\mathrm{KMO}>0.5$, PCA was carried out on the heavy metals of the ten layers of each sediment profile, which yielded two PCs. The loadings of the PCs could indicate the abundance of the heavy metals, where values over 0.7 should be the potential factors [47]. The scores of the PCs could discriminate the similarity and dissimilarity of the sediment layers.

For site \#1 (Fig. 4a), PC1, with $75.66 \%$ of the total variance, had strong positive loadings on $\mathrm{Zn}, \mathrm{Cd}, \mathrm{Ni}$, and $\mathrm{As}$, and negative loadings on $\mathrm{Pb}$. PC2 with $24.14 \%$ of the total variance had positive loadings on $\mathrm{Cu}$. The No. 3 to 5 layers were in the first and fourth quadrants, while the other layers were in the third quadrant and their dispersion was much lower. These behaviors illustrated that $\mathrm{Zn}, \mathrm{Cd}$, As, $\mathrm{Ni}$, and $\mathrm{Cu}$ were potential factors of heavy metal pollution, whose variations were much higher in the No. 3 to 5 layers than those in the other layers (Fig. 4a). For site \#2 (Fig. 4b), PC1 (30.87\%) included Zn, Cr, and Cd, which indicated that these heavy metals were potential factors. The No. 2 to 5 layers were in the third quadrant, while the other layers were in the other three quadrants. This indirectly demonstrates that the variations of the heavy metal in the former were lower than those in the latter. For site \#3 (Fig. 4c), PC1 (26.60\%) contained $\mathrm{Ni}$ and Pb, and PC2 (20.37\%) contained $\mathrm{Zn}$. Interestingly, the PC1 and PC2 scores of the first layer were much larger than those of the other layers, which indirectly proved that the concentrations of $\mathrm{Pb}, \mathrm{Ni}$, and $\mathrm{Zn}$ in the first layer were higher than those in the other layers. Regardless of background, the potential factors of heavy metal pollution mainly included $\mathrm{As}, \mathrm{Cd}, \mathrm{Cu}$, and $\mathrm{Zn}$ in the upstream region, whose concentrations were much higher in the $0-120 \mathrm{~cm}$ region than those in the $120-200 \mathrm{~cm}$ depth, except for $\mathrm{Ni}$ in site \#2.

For site \#4 (Fig. 4d), PC1 (72.39\%) contained Cu, Cd, $\mathrm{Zn}, \mathrm{Ni}, \mathrm{Cr}$, and $\mathrm{Hg}$, increased concentrations of which were the potential factors of heavy metal pollution. The first layer was located on the right side of the $y$-axis, while the remaining layers were on the left side of the y-axis. Furthermore, the No. 7-10 layers were clustered intensively. These results indicate that the heavy metals were enriched in the surface layer (except for the $\mathrm{Pb}$ ), and continuously decreased with the depth. For site \#5 (Fig. 4e), PC1 (73.49\%) contained $\mathrm{Zn}, \mathrm{Cu}, \mathrm{Cr}, \mathrm{Cd}, \mathrm{Hg}$, and As, which were potential factors of heavy metal pollution. The distributions of ten sediment layers were similar to site \#4, which also contributed to the variations of the heavy metals being similar to site \#4. For site \#6 (Fig. 4f), PC1 (81.64\%) again contained $\mathrm{Zn}, \mathrm{Cu}, \mathrm{Cd}, \mathrm{Hg}$, and As. The distribution of ten layers was roughly similar to sites \#4 and \#5, so were the variations of the heavy metals. PC1 (69.45\%) for site \#7 (Fig. 4g) also contained Hg, $\mathrm{Cu}$, As, and $\mathrm{Zn}$, and the variations of the heavy metals were similar to those of \#6. In the midstream, the potential factors of heavy metal pollution were $\mathrm{As}, \mathrm{Cd}, \mathrm{Cu}, \mathrm{Cr}$, $\mathrm{Hg}$, and $\mathrm{Zn}$, whose concentrations were relatively higher in the 0-60 cm layer than those in the 60-200 cm depth range.

For site \#8 (Fig. 4h), PC1 (59.28\%) contained $\mathrm{Cu}, \mathrm{Zn}$, $\mathrm{Cd}$, and As, and PC2 (18.73\%) with Pb. These heavy metals mainly occurred in the surface layer, as the scores in the top layer were the highest. For site \#9, PC1 (47.63\%) contained $\mathrm{Cu}$ and $\mathrm{Hg}$, and PC2 (34.51\%) Zn, Cd, and As. The trend of these heavy metals was similar to that at site \#8. For site \#10, PC1 (69.29\%) had As, Cd, Hg, and Zn, 
(See figure on next page.)

Fig.4 Principal component analysis (PCA) based on the heavy metals of sediments: (a) site \#1, (b) site \#2, (c) site \#3, (d) site \#4, (e) site \#5, (f) site \#6, (g) site \#7, (h) site \#8, (i) site \#9, (j) site \#10. No. 1=0-20 cm; No.2=20-40 cm; No.3=40-60 cm; No.4=60-80 cm; No.5=80-100 cm; No.6=100$120 \mathrm{~cm} ;$ No.7 = 120-140 cm; No.8=140-160 cm; No.9=160-180 cm; No.10=180-200 cm. (variables with weaker impact located at lower left corner)

whose trend was similar to sites \#8 and \#9. Downstream, the potential factors of heavy metal pollution were the same as the midstream, which contained $\mathrm{As}, \mathrm{Cd}, \mathrm{Cu}, \mathrm{Hg}$, and $\mathrm{Zn}$. Diversely, the distributions of the heavy metals were higher at $0-20 \mathrm{~cm}$ than those at $20-200 \mathrm{~cm}$.

\section{Ecological risk assessment Ecological risk of the single heavy metal}

The $E_{r}^{i}$ values of the heavy metals in the sediments were obtained using formula one. According to the grading standards (Table 2), the risk grade of a single heavy metal can be deduced from its $E_{r}^{i}$. For the As (Fig. 5a), Grade II was exhibited at $40-100 \mathrm{~cm}$ at site \#1, where a moderate risk occurred. Grade III exhibited at $0-20 \mathrm{~cm}$ at site $\# 6$, at $0-40 \mathrm{~cm}$ at site $\# 9$, and at $20-40 \mathrm{~cm}$ at site $\# 10$ where the high risk occurred. Grade IV was observed at $0-20 \mathrm{~cm}$ at site \#10, where a very high risk occurred. For Cd (Fig. 5b), Grade V in the upstream occurred at $0-200 \mathrm{~cm}$ at site \#2, at $0-20 \mathrm{~cm}, 40-120 \mathrm{~cm}$, and $160-180 \mathrm{~cm}$ at site $\# 1$, and at $0-20 \mathrm{~cm}$ and $80-200 \mathrm{~cm}$ at site $\# 3$, where disastrous risk was recorded. Grade V in the midstream occurred at $0-20 \mathrm{~cm}$ at site $\# 4$, at $0-40 \mathrm{~cm}$, and $80-100 \mathrm{~cm}$ at site $\# 5$, in $0-20 \mathrm{~cm}, 40-60 \mathrm{~cm}$, and $80-100 \mathrm{~cm}$ at site $\# 6$, and at $0-40 \mathrm{~cm}$ and $100-120 \mathrm{~cm}$ at site \#7. The risk levels decreased with the depth from 120 to $200 \mathrm{~cm}$ at sites \#4 to \#7, which indirectly indicated that the sediment depth could be approximately $120 \mathrm{~cm}$ in the midstream. Grade $\mathrm{V}$ in the downstream occurred at $0-20 \mathrm{~cm}$ at site $\# 8$, at $0-40 \mathrm{~cm}$ and $80-100 \mathrm{~cm}$ at the site \#9, and at $0-20 \mathrm{~cm}$ and $40-100 \mathrm{~cm}$ at site \#10. The trend of the risk levels with the depth was similar to that of the midstream (Fig. 5b). For Cr, all $E_{r}^{i}$ values reached Grade I at all sites, where a low risk occurred (Fig. 5c). For $\mathrm{Cu}$ in the upstream (Fig. 5d), the sediment profile of site \#1 showed the disastrous risk level (Grade $\mathrm{V})$ at $60-80 \mathrm{~cm}$, and high risk (Grade III) at $40-60 \mathrm{~cm}$. The sediment profile of site \#2 was high risk at 100$120 \mathrm{~cm}$, and moderate risk at $0-100 \mathrm{~cm}$ and 120 $140 \mathrm{~cm}$. The sediment profile of the site \#3 was low risk at $0-200 \mathrm{~cm}$. For the midstream (Fig. $5 \mathrm{~d}$ ), a moderate risk occurred at $0-20 \mathrm{~cm}$ at sites $\# 4$ to $\# 7$, except for the site \#6 which showed high risk. For the downstream (Fig. 5d), all sediment profiles were low risk.
For Hg (Fig. 5e), Grade V was found in whole sediment profiles upstream, where the disastrous risk occurred. In the midstream, Grade V was found within the sediment profile of site \#1 (except for $20-60 \mathrm{~cm}$ ), at $0-40 \mathrm{~cm}$ and $60-100 \mathrm{~cm}$ of site $\# 5$, at $0-100 \mathrm{~cm}$ and $120-140 \mathrm{~cm}$ of site $\# 6$, at 0-60 cm and 140-160 cm of site \#7. In the downstream, Grade $V$ was found at $0-60 \mathrm{~cm}$ and $80-160 \mathrm{~cm}$ of site $\# 8$, at $20-140 \mathrm{~cm}$ at site $\# 9$, and at $0-80 \mathrm{~cm}$ and 160 $200 \mathrm{~cm}$ of site \#10. The ecological risk levels of the heavy metals in the sediments were higher in the upstream than those in the midstream and downstream. For Ni (Fig. 5f), Grade III was only found at $80-100 \mathrm{~cm}$ of site \#1, Grade II only at $60-80 \mathrm{~cm}$ of site \#1 and at $0-20 \mathrm{~cm}$ of site \#2, and Grade I widely existed in the other layers. For $\mathrm{Pb}$ (Fig. 5g), Grade I could be completely enriched within the whole sediment profiles at all sites. For $\mathrm{Zn}$ (Fig. 5h), Grade II occurred at $60-100 \mathrm{~cm}$ of site \#1, at $140-160 \mathrm{~cm}$ of site \#2, and at $0-20 \mathrm{~cm}$ of sites \#6 and \#7. Based on the above analyses, the ecological risk levels of $\mathrm{Cd}$ and $\mathrm{Hg}$ were far higher than those of the other heavy metals. Furthermore, the ecological risk levels of $\mathrm{Cd}, \mathrm{Cu}, \mathrm{Ni}$, and $\mathrm{Zn}$ were higher in the upstream than those in the midstream and downstream, while risk level of As was higher in the downstream than those in the upstream and midstream.

\section{Ecological risks of the whole heavy metals}

The PERI of the heavy metals could be calculated using formula one. According to the grading standards (Table 2), the ecological risks of the heavy metals in each sediment layer can be deduced from its PERI (Fig. 6). At almost all sampling sites (except site \#4), surface sediments $(0-40 \mathrm{~cm})$ were defined as being a very high ecological risk. This may indicate that the pollution is a consequence of recent anthropogenic pollution. All sediment layers upstream were defined as being a very high ecological risk, except for 180 $200 \mathrm{~cm}$ of site \#1, where a high ecological risk occurred. Very high ecological risk was found at approximately $0-100 \mathrm{~cm}$ in the midstream sites, high ecological risk at $100-140 \mathrm{~cm}$, and moderate and low risks at 140 $200 \mathrm{~cm}$. The trend of the ecological risks downstream was similar to that in the midstream. These indicated that the ecological risk levels were much higher in the upstream than those in the midstream and downstream. This indirectly proved that the heavy metals in 

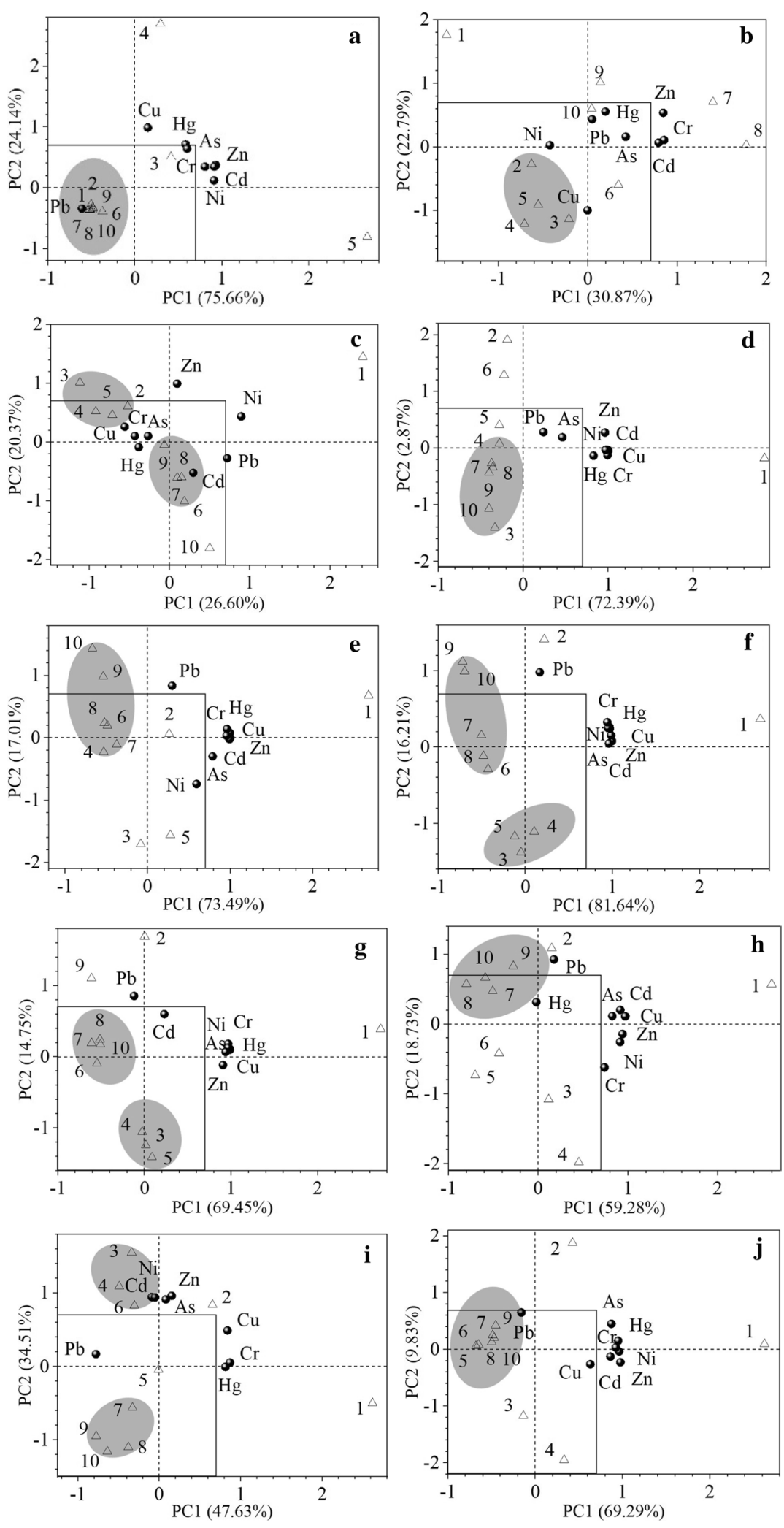


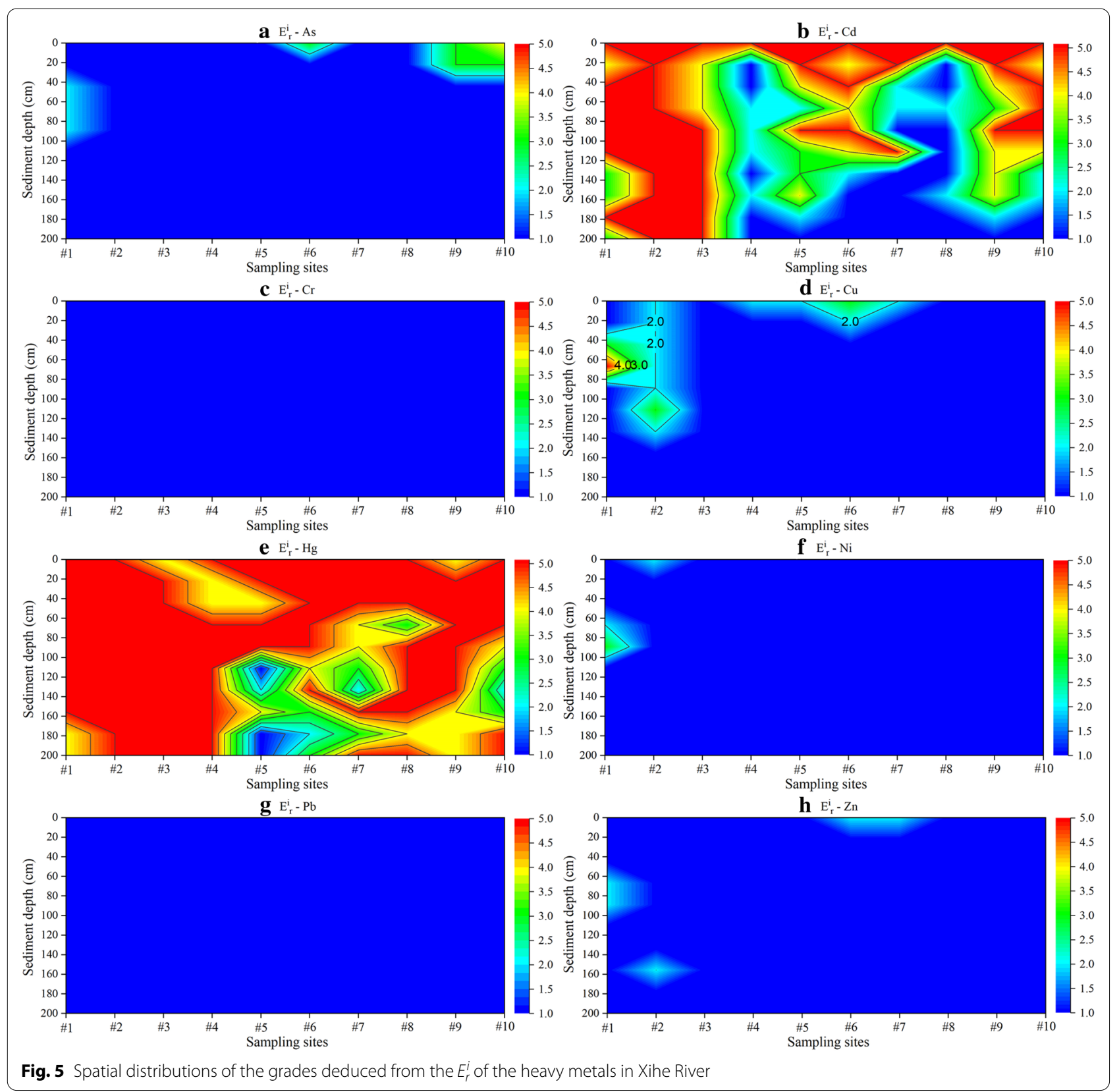

the sediments should be derived from upstream anthropogenic activities.

\section{Conclusions}

The average concentrations of $\mathrm{Ni}, \mathrm{Pb}$, and $\mathrm{Cr}$ in all the sediments were close or slightly higher than their background values in soils in the region, while $\mathrm{As}, \mathrm{Cd}, \mathrm{Cu}$, $\mathrm{Hg}$, and $\mathrm{Zn}$ were significantly higher than their background values. The latter was attributed to a large quantity of effluents from the wastewater treatment plants that entered the river in the upstream region. Furthermore, the average concentration of $\mathrm{Hg}$ was the highest in the midstream, followed by the upstream and downstream regions, indicating that rural domestic sewage had a stronger influence on $\mathrm{Hg}$ pollution than industrial pollutants. The potential factors of heavy metal pollution were $\mathrm{Cd}, \mathrm{Cu}, \mathrm{Hg}, \mathrm{Zn}$, and $\mathrm{As}$, whose ecological risks were much higher than those of $\mathrm{Ni}, \mathrm{Cr}$, and $\mathrm{Pb}$, especially $\mathrm{Cd}$ and $\mathrm{Hg}$. The ecological risk levels of all heavy metals were much higher in the upstream than those in the midstream and downstream. The 


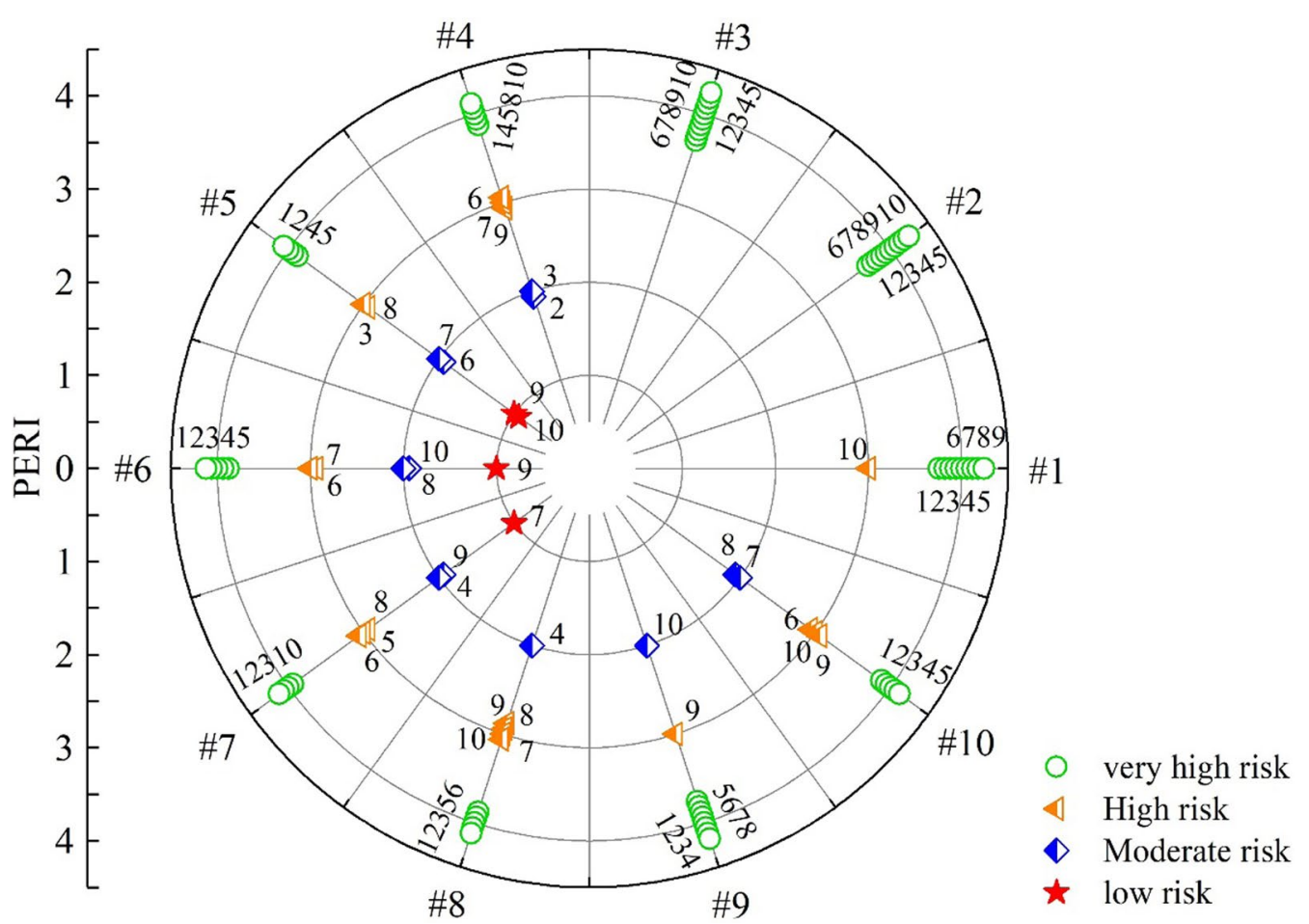

Fig. 6 Distributions of the ecological risks of the heavy metals in Xihe River. No. $1=0-20 \mathrm{~cm} ;$ No.2=20-40 cm; No.3=40-60 cm; No.4=60-80 cm; No.5 = 80-100 cm; No.6 = 100-120 cm; No.7=120-140 cm; No.8 =140-160 cm; No.9=160-180 cm; No.10=180-200 cm

results showed that efficient solutions must be found to protect the environmental quality of urban rivers.

\section{Abbreviations}

CCA: Canonical correlation analysis; PCA: Principal component analysis; PC: Principal components; PERI: Potential ecological risk index; No. 1: 0-20 Cm; No.2: 20-40 Cm; No.3: 40-60 Cm; No.4: 60-80 Cm; No.5: 80-100 Cm; No.6: 100-120 Cm; No.7: 120-140 Cm; No.8: 140-160 Cm; No.9: 160-180 Cm; No.10: $180-200 \mathrm{Cm}$.

\section{Acknowledgements}

We would like to express our sincere thanks to the anonymous reviewers. Their insightful comments were helpful for improving the manuscript.

\section{Authors' contributions}

DL carried out the experiments, analyzed the data and wrote the manuscript; $\mathrm{HY}$ and $\mathrm{HG}$ analyzed the data and modified the manuscript; WX wrote the manuscript and improved the language of the manuscript. All authors read and approved the final manuscript

\section{Funding}

This work was financially supported by the Chinese Major Science and Technology Program for Water Pollution Control and Treatment (Grant No. 2018ZX07111001, P.R. China) and Environmental Protection Science and Technology Research Project of the Ningxia Hui Autonomous Region of China (Number, 2019).

\section{Availability of data and materials}

The datasets obtained and analyzed in the research is available from the first author on reasonable request.

\section{Declarations}

Ethics approval and consent to participate

Not applicable.

\section{Consent for publication}

Not applicable.

\section{Competing interests}

The authors declare no conflict of interest.

\section{Author details}

${ }^{1}$ State Key Laboratory of Environmental Criteria and Risk Assessment, Chinese Research Academy of Environmental Science, Beijing 100012, People's Republic of China. ${ }^{2}$ State Key Joint Laboratory of Environment Simulation and PolIution Control, School of Environment, Tsinghua University, Beijing 100084, China.

Received: 8 December 2020 Accepted: 22 March 2021

Published online: 31 March 2021

\section{References}

1. Irabien MJ, Velasco F (1999) Heavy metals in Oka river sediments (Urdaibai National Biosphere Reserve, northern Spain): lithogenic and anthropogenic effects. Environ Geol 37:54-63

2. Yu RL, Yuan X, Zhao YH, Hu GR, Tu XL (2008) Heavy metal pollution in intertidal sediments from Quanzhou Bay, China. J Environ Sci 20:664-669

3. Ferati F, Kerolli-Mustafa M, Kraja-Ylli A (2015) Assessment of heavy metal contamination in water and sediments of Trepca and Sitnica rivers, Kosovo, using pollution indicators and multivariate cluster analysis. Environ Monit Assess 187:338-338 
4. Guo B, Liu Y, Zhang F, Hou J, Zhang H, Li C (2018) Heavy metals in the surface sediments of lakes on the Tibetan Plateau, China. Environ Sci Pollut Res 25:3695-3707

5. Luoma SN, Bryan GW (1981) A statistical assessment of the form of trace metals in oxidized estuarine sediments employing chemical extractants. Sci Total Environ 17(2):165-196

6. Li CL, Kang SC, Zhang QG, Gao SP, Sharma CM (2011) Heavy metals in sediments of the Yarlung Tsangbo and its connection with the arsenic problem in the Ganges-Brahmaputra Basin. Environ Geochem Health 33:23-32

7. Varol M (2011) Assessment of heavy metal contamination in sediments of the Tigris River (Turkey) using pollution indices and multivariate statistical techniques. J Hazard Mater 195:355-364

8. Christophoridis C, Dedepridis D, Fytianos K (2009) Occurrence and distribution of selected heavy metals in the surface sediments of Thermaikos Gulf, N. Greece. Assessment using pollution indicators. J Hazard Mater 168:1082-1091

9. Bai JH, Cui BS, Chen B, Zhang KJ, Deng W, Gao HF, Xiao R (2011) Spatial distribution and ecological risk assessment of heavy metals in surface sediments from a typical plateau lake wetland, China. Ecol Model 222:301-306

10. Bastami KD, Neyestani MR, Shemirani F, Soltani F, Haghparast S, Akbari A (2015) Heavy metal pollution assessment in relation to sediment properties in the coastal sediments of the southern Caspian Sea. Mar Pollut Bull 92:237-243

11. Davutluoglu OI, Seckin G, Ersu CB, Yilmaz T, Sari B (2011) Heavy metal content and distribution in surface sediments of the Seyhan River, Turkey. J Environ Manage 92:2250-2259

12. Superville PJ, Prygiel E, Magnier A, Lesven L, Gao Y, Baeyens W (2014) Daily variations of $\mathrm{Zn}$ and $\mathrm{Pb}$ concentrations in the Defile River in relation to the resuspension of heavily polluted sediments. Sci Total Environ 470:600-607

13. Singh UK, Kumar B (2017) Pathways of heavy metals contamination and associated human health risk in Ajay River Basin, India. Chemosphere 174:183-199

14. Bharath K, David AT, Gert RG (2011) A majorization-minimization approach to the sparse generalized eigenvalue problem. Mach Learn 85(1-2):3-39

15. Tokalioglu E, Kartal S (2006) Multivariate analysis of the data and speciation of heavy metals in street dust samples from the Organized Industrial District in Kayseri (Turkey). Atmospheric Environ 40(16):2797-2805

16. Liu QZ, Liu AP, Zhang X, Chen X, Qian RB (2019) Removal of EMG artifacts from multichannel EEG signals using combined singular spectrum analysis and canonical correlation analysis. J Healthc Eng 4159676:1-13

17. Rahman MATMT, Hoque S, Saadat AHM (2017) Selection of minimum indicators of hydrologic alteration of the Gorai river, Bangladesh using principal component analysis. Sustainable Water Resour Manag 3:13-23

18. Qiao Y, Yang Y, Gu J, Zhao J (2013) Distribution and geochemical speciation of heavy metals in sediments from coastal area suffered rapid urbanization, a case study of Shantou Bay, China. Mar Pollut Bull 68:140-146

19. Neyestani MR, Bastami KD, Esmaeilzadeh M, Shemirani F, Khazaali A, Molamohyeddin N, Afkhami M, Nourbakhsh S, Dehghani M, Aghaei S (2016) Geochemical speciation and ecological risk assessment of selected metals in the surface sediments of the northern Persian Gulf. Mar Pollut Bull 109(1):603-611

20. Xu FJ, Qiu LW, Cao YC, Huang JL, Liu ZQ, Tian X, Li AC, Yin XB (2016) Trace metals in the surface sediments of the intertidal Jiaozhou Bay, China: sources and contamination assessment. Mar Pollut Bull 104:371-378

21. Liu JJ, Ni ZX, Diao ZH, Hu YX, Xu XR (2018) Contamination level, chemical fraction and ecological risk of heavy metals in sediments from Daya Bay, South China Sea. Mar Pollut Bull 128:132-139

22. Özkan EY (2012) A new assessment of heavy metal contaminations in an eutrophicated bay (Inner Izmir Bay, Turkey). Turk J Fish Aquat Sci 12:135-147

23. Moore F, Forghani G, Qilshlaqi A (2009) Assessment of heavy metal contamination in water and surface sediments of the Maharlu saline Lake, SW Iran. Iran J Sci Technol Trans A Sci 33:43-55

24. Xu G, Pei S, Liu J, Gao M, Hu G, Kong X (2015) Surface sediment properties and heavy metal pollution assessment in the near-shore area, north Shandong Peninsula. Mar Pollut Bull 95:395-401
25. Sundaramanickam A, Shanmugam N, Cholan S, Kumaresan S, Madeswaran P, Balasubramanian T (2016) Spatial variability of heavy metals in estuarine, mangrove and coastal ecosystems along Parangipettai, Southeast coast of India. Environ Pollut 218:186-195

26. Zhu HN, Yuan XZ, Zeng GM, Jiang $M$, Liang J, Zhang C, Yin Z, Huang $H J$, Liu ZF, Jiang HW (2012) Ecological risk assessment of heavy metals in sediments of Xiawan Port based on modified potential ecological risk index. T Nonferr Metal Soc 22:1470-1477

27. Guo W, He M, Yang Z (2011) Aliphatic and polycyclic aromatic hydrocarbons in the Xihe River, an urban river in China's Shenyang City: distribution and risk assessment. J Hazard Mater 186(2-3):1193-1199

28. Zhang J, Fan SK (2016) Consistency between health risks and microbial response mechanism of various petroleum components in a typical wastewater-irrigated farmland. J Environ Manage 174:55-61

29. Yu HB, Song YH, Du E, Yang N, Peng JF, Liu RX (2016) Comparison of PARAFAC components of fluorescent dissolved and particular organic matter from two urbanized rivers. Environ Sci Pollut Res 23(11):1-12

30. Yap CK, Pang BH (2011) Assessment of Cu, Pb, and Zn contamination in sediment of north western Peninsular Malaysia by using sediment quality values and different geochemical indices. Environ Monit Assess 183:23-39

31. Zhang LL, Liu JL (2014) In situ relationships between spatial-temporal variations in potential ecological risk indexes for metals and the short-term effects on periphyton in a macrophyte-dominated lake: a comparison of structural and functional metrics. Ecotoxicology 23(4):553-566

32. CNEMC (China National Environmental Monitoring Centre) (1990) Background values of elements in China soil. China Environmental Science Press, Beijing, pp 342-378

33. Zhang Z, Juying L, Mamat Z, QingFu Y (2016) Sources identification and pollution evaluation of heavy metals in the surface sediments of Bortala River, Northwest China. Ecotoxicol Environ Saf 126:94-101

34. Guo X, Yuan D, Jiang J, Zhang H, Deng Y (2013) Detection of dissolved organic matter in saline-alkali soils using synchronous fluorescence spectroscopy and principal component analysis. Spectro Chim Acta A 104:280-286

35. Zhu Y, Song Y, Yu H, Liu R, Liu L, Lv C (2017) Characterization of dissolved organic matter in Dongjianghu Lake by UV-visible absorption spectroscopy with multivariate analysis. Environ Monit Assess 189:443-452

36. Kumolu-Johnson C, Ndimele P, Akintola S, Jibuike C (2010) Copper, zinc and iron concentrations in water, sediment and Cynothrissa mento (Regan 1917) from Ologe Lagoon, Lagos, Nigeria: a preliminary survey. J Limnol Soc Southern Afr 35(1):87-94

37. Kassegne AB, Esho TB, Okonkwo JO, Asfaw SL (2018) Distribution and ecological risk assessment of trace metals in surface sediments from Akaki River catchment and Aba Samuel reservoir, Central Ethiopia. Environ Syst Res 7:7-24

38. Wu QH, Zhou HC, Nora FY, Tian Y, Tan Y, Zhou S, Li Q, Chen YH, Jonathan YS (2016) Contamination, toxicity and speciation of heavy metals in an industrialized urban river: implications for the dispersal of heavy metals. Mar Pollut Bull 104(1-2):153-161

39. Liu CC, Yin J, Hu J, Zhang B (2020) Spatial distribution of heavy metals and associated risks in sediment of the Urban River flowing into the Pearl River Estuary China. Arch Environ Contam Toxicol 78(4):622-630

40. Xiao R, Bai J, Huang L, Zhang H, Cui B, Liu X (2013) Distribution and pollution, toxicity and risk assessment of heavy metals in sediments from urban and rural rivers of the Pearl River delta in southern China. Ecotoxicology 22(10):1564-1575

41. Islam MS, Ahmed MK, Raknuzzaman M, Habibullah-Al-Mamun Md, Islam MK (2015) Heavy metal pollution in surface water and sediment: a preliminary assessment of an urban river in a developing country. Ecol Indic 48:282-291

42. Sekabira K, Origa HO, Basamba TA, Mutumba G, Kakudidi E (2010) Assessment of heavy metal pollution in the urban stream sediments and its tributaries. Int J Environ Sci Te 7(3):435-446

43. Wang AJ, Kawser A, Xu YH, Ye X, Rani S, Chen KL (2016) Heavy metal accumulation during the last 30 years in the Karnaphuli River estuary, Chittagong, Bangladesh. Springerplus 5:2079-2092

44. Nawrot N, Wojciechowska E, Matej-Łukowicz K, Walkusz-Miotk J, Pazdro K (2020) Spatial and vertical distribution analysis of heavy metals in urban retention tanks sediments: a case study of Strzyza Stream. Environ Geochem Health 42:1469-1485 
45. Zuzolo D, Cicchella D, Catani V, Giaccio L, Guagliardi I, Esposito L, Vivo BD (2017) Assessment of potentially harmful elements pollution in the Calore River basin (Southern Italy). Environ Geochem Health 39:531-548

46. Wang XQ, Liu XM, Wu H, Tian M, Li RH, Chao SZ (2020) Interpretations of $\mathrm{Hg}$ anomalous sources in drainage sediments and soils in China. J Geochem Explor. 224:106711

47. Wei HB, Yu HB, Zhang GC, Pan HW, Lv CJ, Meng FS (2018) Revealing the correlations between heavy metals and water quality, with insight into the potential factors and variations through canonical correlation analysis in an upstream tributary. Ecol Indic 90:485-493

48. He W, Lee J, Hur J (2016) Anthropogenic signature of sediment organic matter probed by UV-Visible and fluorescence spectroscopy and the association with heavy metal enrichment. Chemosphere 150:184-193

49. Liu DP, Yu HB, Gao HJ, Feng HJ, Zhang GC (2021) Applying synchronous fluorescence and UV-vis spectra combined with two-dimensional correlation to characterize structural composition of DOM from urban black and stinky rivers. Environ Sci Pollut Res 2:1-12

50. Guo XJ, Yuan DH, Jiang JY, Zhang H, Deng Y (2013) Detection of dissolved organic matter in saline-alkali soils using synchronous fluorescence spectroscopy and principal component analysis. Spectrochim Acta A 104:280-286

51. Santos LM, Simões ML, Melo WJ, Martin-Neto L, Pereira-Filho LE (2010) Application of chemometric methods in the evaluation of chemical and spectroscopic data on organic matter from Oxisols in sewage sludge applications. Geoderma 155:121-127

\section{Publisher's Note}

Springer Nature remains neutral with regard to jurisdictional claims in published maps and institutional affiliations.

\section{Submit your manuscript to a SpringerOpen ${ }^{\circ}$ journal and benefit from:}

- Convenient online submission

- Rigorous peer review

- Open access: articles freely available online

- High visibility within the field

- Retaining the copyright to your article

Submit your next manuscript at $\boldsymbol{\nabla}$ springeropen.com 